\title{
Pathobiology of Neurosarcoidosis and Clinicopathologic Correlation
}

\author{
Herbert J. Manz
}

SUMMAR Y: In a retrospective study of 4,294 consecutive postmortem cases, there were 15 with histologically proved sarcoidosis, including 4 with CNS involvement. Whereas in previously reported autopsy series the prevalence of neurosarcoidosis was $15 \%$, it is $27 \%$ in this review. Five cases with incidental, clinically inapparent sarcoidosis died at a mean age of 54.6 years; those six with systemic sarcoidosis, not involving the CNS, died at a mean age of 47.0 years; while those four with a variety of neurologic manifestations in addition to systemic sarcoidosis died at a mean age of 38.2 years. Thus, it appears that at one end of the spectrum of morbidity, sarcoidosis may cause no or only trivial symptoms and permit prolonged survival. At the other extreme, sarcoidosis may affect a younger population more severely. CNS involvement occurs relatively early in the course and is rather rapidly progressive, accounting for the poor prognosis, despite appropriate medical and neurosurgical management. In its turn, neurosarcoidosis may present with a variety of signs and symptoms, depending on the site of involvement along the craniospinal axis. This feature is illustrated by the manifestations of compression myelopathy, hydrocephalus with dementia, hydrocephalus with seizures and ataxia, and anosmia, blindness, seizures, and diabetes insipidus. In addition, one patient developed a Nocardia brain abscess as a complication of the altered immune system in sarcoidosis.

RÉSUMÉ: Nous avons trouvé 15 cas de sarcoidose prouvés histologiquement, dont 4 avec atteinte du SNC, dans une étude rétrospective de 4294 cas consécutifs d'autopsie. Dans les études préalablement publiées, la prévalence de neurosarcoidose était de $15 \%$ alors qu'elle est de $27 \%$ dans la présente série. Chez les 5 patients dont la sarcoidose était cliniquement inapparente, la mort s'est produite à l'àge moyen de 54.6 ans; chez les 6 patients avec sarcoidose systémique, mais sans atteinte neurologique, l'âge moyen du décès était de 47.0 ans; enfin, chez les 4 patients présentant des manifestations neurologiques et une sarcoidose systémique, l'âge moyen du décès est de 35.0 ans. Il semble donc qu'à une extrémité de l'éventail morbide, la sarcoidose peut être silencieuse et permettre une longue survie; tandis qu'â l'autre extrémité la sarcoidose peut atteindre plus sévèrement une population plus jeune. L'atteinte du SNC se produit généralement relativement tôt et est rapidement progressive, ce qui explique le mauvais pronostic malgré les traitements médicaux et chirurgicaux appropriés. La neurosarcoidose peut se présenter de façon très variée selon le site d'atteinte le long de l'axe cranio-spinal et imiter: une myélopathie compressive, une hydrocéphalie avec démence, une hydrocéphalie avec épilepsie et ataxie; anosmie, cécité, crises épileptiques, diabète insipide, troubles neuropsychiatriques, diplopie et troubles neuroendocriniens. Ün autre patient, dont le système immun était altéré par la sarcoidose, a développé un abcès cérébral à la Nocardia.

Can.J. Neurol. Sci. 1983; 10:50-55

As a granulomatous disease of undetermined etiology but with a significant component of immune dysregulation, sarcoidosis may affect any tissue. Involvement of the central nervous and neuromuscular systems has been reported with some frequency (Aszkanazy, 1952; Day and Sypert, 1977; Delaney, 1977; Waxman and Sher, 1979). Commonly, "sarcoidosis of the nervous system" has been applied collectively to cases with involvement of the craniospinal axis and of the peripheral nervous and muscular systems. It has also been taught empirically that neurosarcoidosis has a much poorer prognosis for quality of survival and longevity when compared to other forms of the disease. Through a retrospective postmortem review, I wish to illustrate this trend and the clinico-pathologic correlation.

\section{MATERIALS AND METHODS}

Postmortem records at Georgetown University Hospital (GUH) for the years 1966 to 1981 were reviewed to select cases listing sarcoidosis as a histopathologic diagnosis. Among the 4,294 postmortem cases, there were 19 so classified. Four cases were excluded because non-caseating or obsolescent granulomas were confined to a single med- iastinal or hilar lymph node or the spleen. The remaining 15 cases (12 Black, 3 White; 8 male, 7 female) form the basis of this study.

Whenever the clinical abstract in the autopsy protocol was incomplete, the patient's entire hospital records were reviewed. Histologic slides, stained with a battery of histochemical procedures, were studied.

\section{RESULTS}

The prevalence of sarcoidosis in the 4,294 postmortem cases was 15 , or $0.35 \%$. These 15 cases are grouped into three major categories.

I. Incidental, postmortem diagnosis of sarcoid granulomas: 5 cases, having a mean age of 54.6 years (range, 40 to 77 years; 3 males, 2 females; 3 Black, 2 White).

II. Systemic sarcoidosis, clinically manifest, proved by biopsy, and confirmed postmortem: 6 cases, with a mean age of 47.0 years (range, 28-72 years; 2 males, 4 females; 5 Black, one White). The mean duration of sarcoidosis for this group was 6.7 years (range, 2 to 12

From the Department of Pathology, Georgetown University, Washington, D.C.

Received November 2, 1981 . Accepted for publication August 19, 1982.

Requests for Reprints to Dr. H.J. Manz, Department of Pathology, Georgetown University Medical Center, 3900 Reservoir Road, N.W., Washington, D.C. 20007 U.S.A. 
TABLE 1:

Clinical and pathological features of four cases of neurosarcoidosis

\begin{tabular}{|c|c|c|c|c|c|c|c|c|}
\hline & Age/ & race & sex & $\begin{array}{l}\text { Total duration } \\
\text { of sarcoidosis }\end{array}$ & $\begin{array}{l}\text { CNS signs and } \\
\text { symptoms }\end{array}$ & $\begin{array}{c}\text { Duration of CNS } \\
\text { signs \& symptoms }\end{array}$ & Neuropathology & $\begin{array}{l}\text { Other pertinent } \\
\text { findings }\end{array}$ \\
\hline 1 & 27 & B & $\mathbf{M}$ & 4 years & $\begin{array}{l}\text { Spasticity, } \\
\text { paraparesis, } \\
\text { dementia }\end{array}$ & 3 months & $\begin{array}{l}\text { Lentiform nuclei, } \\
\text { leptomeninges; } \\
\text { (vertebrae) }\end{array}$ & $\begin{array}{l}\text { mental retardation, } \\
\text { T7-9 collapse }\end{array}$ \\
\hline 2 & 61 & B & $\mathbf{M}$ & 5 years & $\begin{array}{l}\text { Hyperreflexia } \\
\text { dementia, } \\
\text { nystagmus, } \\
\text { seizures }\end{array}$ & 3 years & $\begin{array}{l}\text { Ependyma, } \\
\text { meninges, nerves, } \\
\text { hydrocephalus }\end{array}$ & $\begin{array}{l}\text { Hypersplenism } \\
3 \text { years earlier }\end{array}$ \\
\hline 3 & 36 & B & M & 14 years & $\begin{array}{l}\text { Seizures, } \\
\text { ataxia }\end{array}$ & 10 years & $\begin{array}{l}\text { Meninges, } \\
\text { hydrocephalus }\end{array}$ & $\begin{array}{l}\text { Ventriculo-atrial } \\
\text { shunt; cor pulmonale }\end{array}$ \\
\hline 4 & 29 & B & $\mathrm{F}$ & 6 years & $\begin{array}{l}\text { Anosmia, } \\
\text { blindness, } \\
\text { seizures, } \\
\text { diabetes } \\
\text { insipidus }\end{array}$ & 3 years & $\begin{array}{l}\text { Meninges, } \\
\text { hypothalamus, } \\
\text { pituitary, } \\
\text { spinal cord }\end{array}$ & $\begin{array}{l}\text { T7 compression; } \\
\text { decubitus ulcer } \\
\text { with atypical } \\
\text { mycobacteria }\end{array}$ \\
\hline $\begin{array}{l}\text { additional } \\
\text { case }\end{array}$ & 122 & W & $M$ & 2 years & $\begin{array}{l}\text { Headache, } \\
\text { diplopia, } \\
\text { ataxia, } \\
\text { diabetes } \\
\text { insipidus, } \\
\text { neuropsy- } \\
\text { chiatric } \\
\text { problems }\end{array}$ & 2 years & $\begin{array}{l}\text { Meninges, } \\
\text { brain, } \\
\text { cord, cranial } \\
\text { and spinal } \\
\text { nerves, pituitary, } \\
\text { cerebral blood } \\
\text { vessels }\end{array}$ & $\begin{array}{l}\text { Cerebral } \\
\text { infarcts }\end{array}$ \\
\hline
\end{tabular}

years). A 40-year old Black man, with sarcoidosis for 5 years, died of Nocardia asteroides brain abscess of six weeks' duration, despite surgical and anti-biotic management.

III. Systemic sarcoidosis with neurologic and pathologic documentation of involvement of the craniospinal axis (see Table 1): 4 cases, having a mean age of 38.2 years (range, 27 to 61 years; 3 males, 1 female; all were Black). The total course of sarcoidosis averaged 7.2 years (range, 4 to 14 years) with a mean duration of CNS symptomatology of 4.0 years (range, 3 months to 10 years).

The prevalence of neurosarcoidosis in this series of 15 postmortem cases of sarcoidosis at GUH over a 15-year period is thus $4 / 15$ or $27 \%$.

\section{CASE REPORTS}

\section{Case 1}

An epileptic Black man with moderate mental retardation was discovered to have a left hilar lymphadenopathy and bilateral pneumonitis on chest X-rays at age 23 years. Lack of radiographic resolution with antibiotic therapy prompted a liver biopsy, which demonstrated noncaseating epithelioid granulomas. Approximately three months prior to death at age 27 years, he became progressively more demented and spastic. He died of staphylococcal abscess in the upper lobe of the right lung after several days of fever. Massive, generalized lymphadenopathy was due to epithelioid and giant cell granulomas and hyaline nodular fibrosis. Liver, spleen, lungs and thoracic vertebrae also contained multiple granulomas. The midthoracic vertebrae were pathologically fractured. The lentiform nuclei were partly destroyed by numerous epitheloid cell granulomas containing giant cells and lymphocytes. Special stains fail to disclose microorganisms.
Case 2

An admission chest $\mathrm{X}$-ray disclosed bilateral hilar and mediastinal lymphadenopathy in a 57 year old Black man. Cervical lymph node biopsy demonstrated granulomas consistent with sarcoidosis. Two years later, pancytopenia secondary to splenomegaly from sarcoidosis necessitated splenectomy. Several months later he was readmitted for progressive dyspnea, weakness, anorexia, weight loss, lethargy, and dementia. Lumbar puncture revealed clear CSF under normal pressure but containing $231 \mathrm{mg} \%$ protein and $52 \mathrm{mg} \%$ glucose. Diffuse slowing of electrical activity was evident on the EEG, but bilateral carotid arteriography was unremarkable. After a further year, he developed gait disturbances and memory loss. Vertical nystagmus and bilateral Babinski responses were detected. The CSF protein was $391 \mathrm{mg} \%$ and glucose $34 \mathrm{mg} \%$. Despite steroid therapy, his level of consciousness fluctuated and he had occasional grand mal seizures only partly controlled with Dilantin. At age 61 years, he was found at home with a high fever due to bilateral bronchopneumonia and expired on the day of admission.

Innumerable sclerosing and hyalinized granulomas were scattered through multiple lymph node groups, liver, cranial and spinal leptomeninges, anterior and posterior spinal nerve roots, and cerebral ventricular walls.

Case 3

Hilar lymphadenopathy was the first evidence of sarcoidosis in a 24 year old Black man. Four years later, focal and generalized tonic/clonic seizures appeared. Twelve years after the diagnosis of sarcoidosis, he suffered intermittent gait ataxia secondary to hydrocephalus; the CSF contained elevated protein and gammaglobulin. Isotope cisternography disclosed subarachnoid block in the ambient and interpenducular cisterns. A ventriculoatrial shunt was placed. On the first postoperative day he complained of slight headache, became confused and lethargic, and was found without vital signs some hours later. Sarcoid granulomas involved the lungs, hilar lymph nodes, spleen, pancreas, and leptomeninges, especially those about the outflow foramina from the fourth ventricule, and caused hydrocephalus (Fig. 1). 


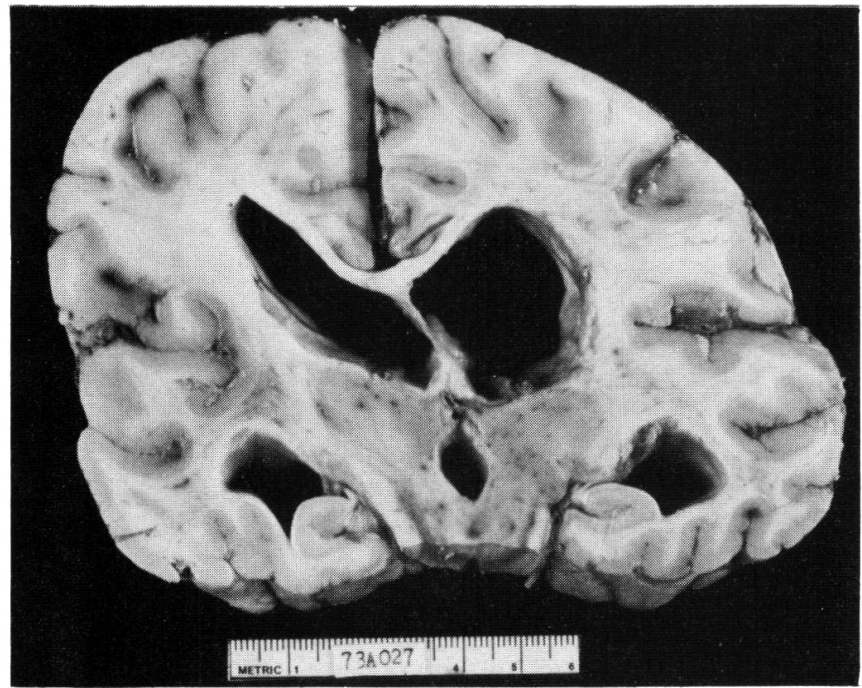

Figure 1 - This coronally sectioned cerebrum reveals moderate hydrocephalus $(x 0.7)$

\section{Case 4}

A 23-year old Black woman had uveitis and dyspnea due to sarcoidosis; she was treated with topical and systemic steroids, but developed complete blindness within 3 years. She developed amenorrhea, headaches, lethargy, and grand mal seizures. Lumbar puncture procured CSF at an opening pressure exceeding $600 \mathrm{~mm}$ water; protein was 143 $\mathrm{mg} / \mathrm{dl}$, glucose $30 \mathrm{mg} / \mathrm{dl}$, and there were 30 lymphocytes; smear and cultures were negative. Brain scan revealed increased uptake over both hemispheres. Anticonvulsants provided good seizure control. Subsequent admissions over 3 years were for diabetes insipidus, elevated intracranial pressure, neuroendocrine abnormalities, and dysosmia. CSF was now xanthochromic, with pressure of $240 \mathrm{~mm}$ water, protein of $635 \mathrm{mg} / \mathrm{dl}$, glucose of $20 \mathrm{mg} / \mathrm{dl}$, and no cells. Cranial CT scan demonstrated enlarged ventricles. Terminally, she acquired an atypical scotochromogenic mycobacterial ulcer of the sacrum and hip. She suffered a cardiorespiratory arrest after aspiration.

Postmortem study revealed systemic sarcoidosis. The brain weighed $1050 \mathrm{gm}$. The basal meninges were markedly fibrotic and multiple cranial nerves were severely atrophic or infiltrated by granulomas (Fig. 2). The pituitary gland weighed only $280 \mathrm{mg}$. and was largely replaced by fibrous scar tissue. Most of the hypothalamus was gliotic or was occupied by obsolescent and epithelioid cell granulomas. The spinal cord (Fig. 3) and nerve roots were affected. Leptomeningeal cultures were negative and special stains of the intracranial contents failed to demonstrate microorganisms.

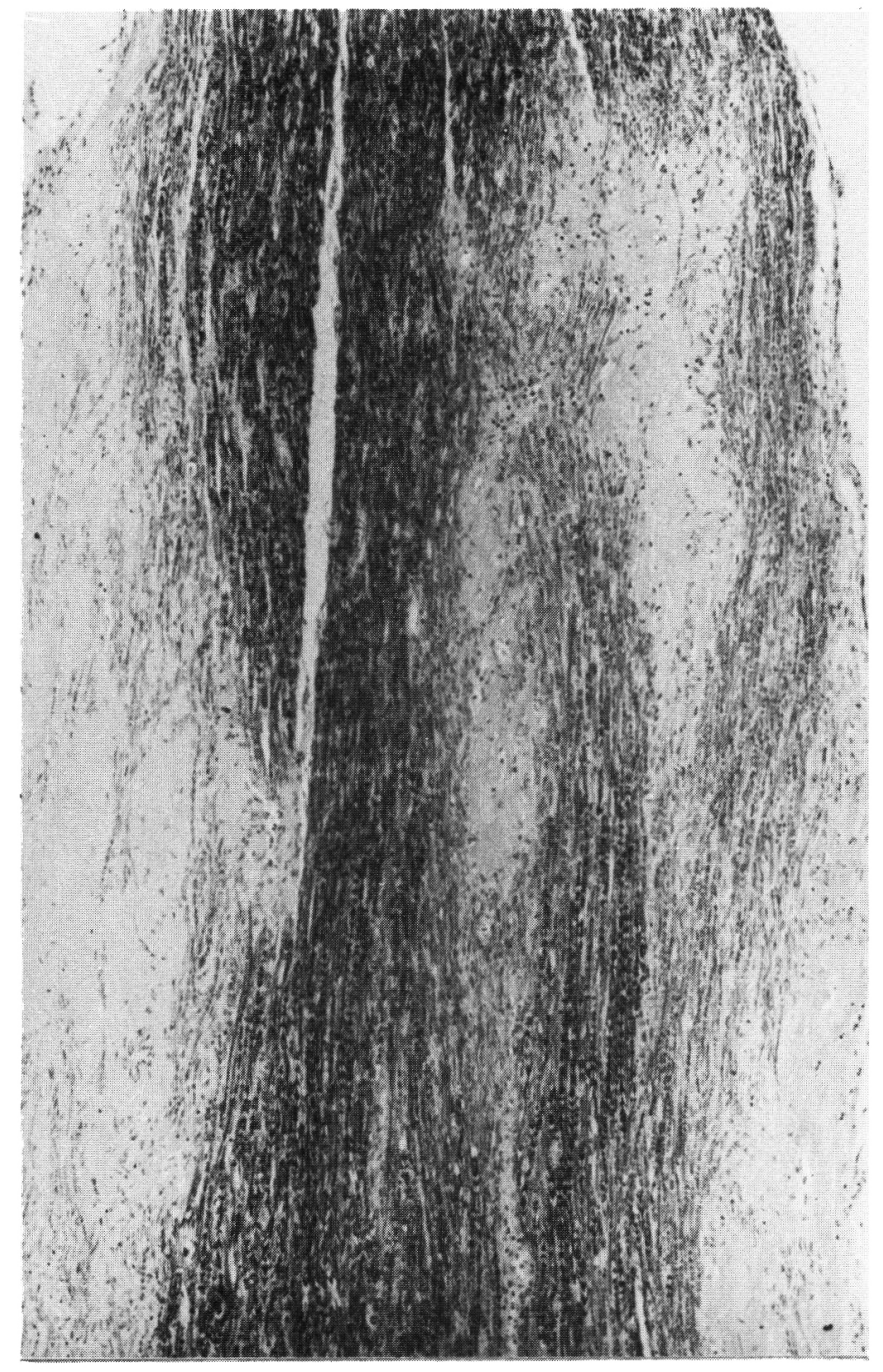

Figure 2 - Several spindle-shaped, hyalinized granulomas have distorted and focally destroyed the oculomotor nerve (LFB; $x 63$ )

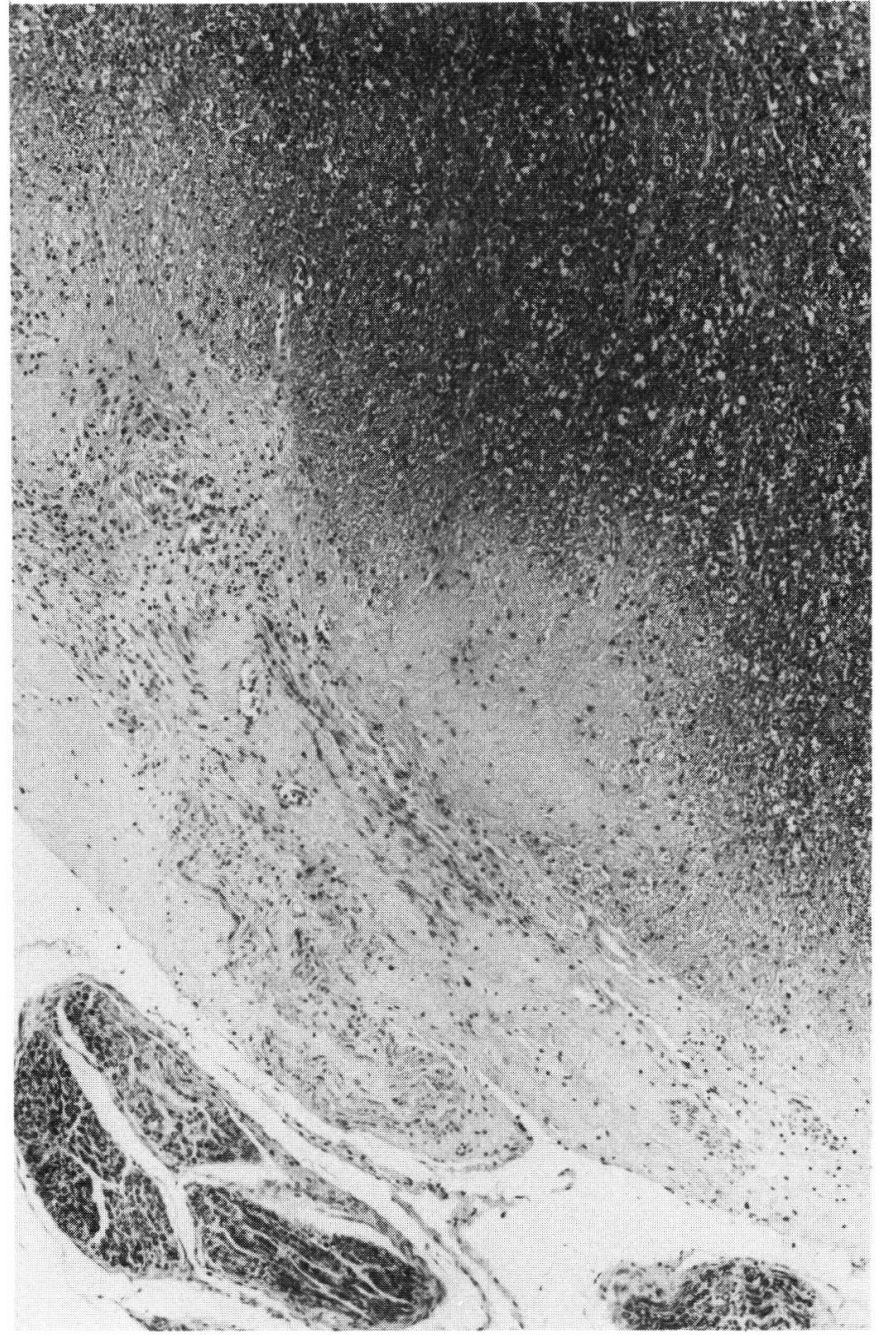

Figure 3 - The peripheral rim of spinal cord at the point of exit of cervical anterior nerve roots demonstrates gliosis and hyaline scarring of old granulomas (LFB; 663 ) 
The following additional case which illustrates some special aspects of neurosarcoidosis was obtained from the records of the Kingston General Hospital.

Two years before death at age 22 years, this white man noted headaches, diplopia, episodic vomiting, and progressive weight gain. EEG indicated a deep midline lesion. Some months later, vertigo, gait ataxia, papilledema, a left Babinski sign, and generalized hyporeflexia developed. Skull films demonstrated erosion of the sella tursica and brain scan revealed a right temporal mass. CSF was xanthochromic, with protein $233 \mathrm{mg} / \mathrm{dl}$ and glucose $25 \mathrm{mg} / \mathrm{dl}$; it contained 30 lymphocytes and was sterile. Pneumoencephalography demonstrated communicating hydrocephalus. Steroid therapy improved neurologic dysfunctions temporarily, then fluctuating levels of mental status, Horner's syndrome, polyuria and polydipsia ensued. The CSF had an opening pressure of 350 $\mathrm{mm}$ water, protein of $338 \mathrm{mg} / \mathrm{dl}$, glucose $16 \mathrm{mg} / \mathrm{dl}$, and 21 lymphocytes; cultures and cytology were negative. A ventriculoatrial shunt controlled hydrocephalus and injections of vasopressin relieved diabetes insipidus. Brain biopsy revealed thickened leptomeninges with mononuclear cells, but a cervical lymph node and Kveim test biopsy demonstrated noncaseating granulomas. During the last six months of life, the patient developed progressive Cushingoid features, visual failure, ataxia, somnolence, dementia, quadriparesis, hyperthermia, seizures, psychiatric abnormalities, and bilateral Babinski signs. He died of aspiration pneumonia.

Multiple organs and tissues contained sarcoid granulomas. The brain weighed $1695 \mathrm{gm}$, the blood vessels were congested, and the basal leptomeninges granular and thickened, trapping the cranial nerves (Fig. 4). All components of the craniospinal axis were extensively infiltrated by sarcoid granulomas, so as to obliterate the fourth ventricular outflow foramina (Fig. 5) and to strangle cranial nerves. The hypophysis was largely destroyed (Fig. 6). Special stains and electron microscopy failed to demonstrate microorganisms. Several arteries and veins exhibited granulomatous angiitis, fibrinoid necrosis, and thrombosis (Fig. 7). A portion of occipital lobe was infarcted.

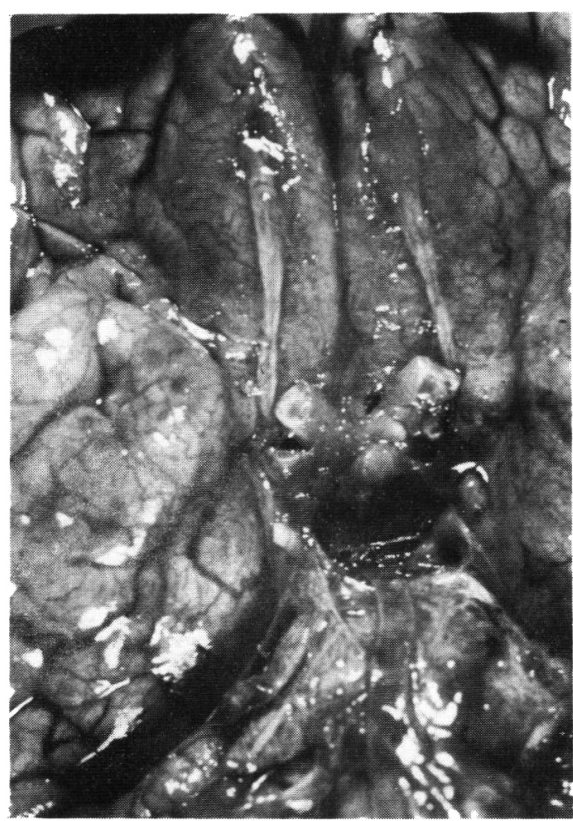

Figure 4 - Basal surface of brain depicts vascular congestion, opacification of leptomeninges, and enlargement of optic nerves and infundibular stalk due to granulomatous infiltration $(x$ 1.2)

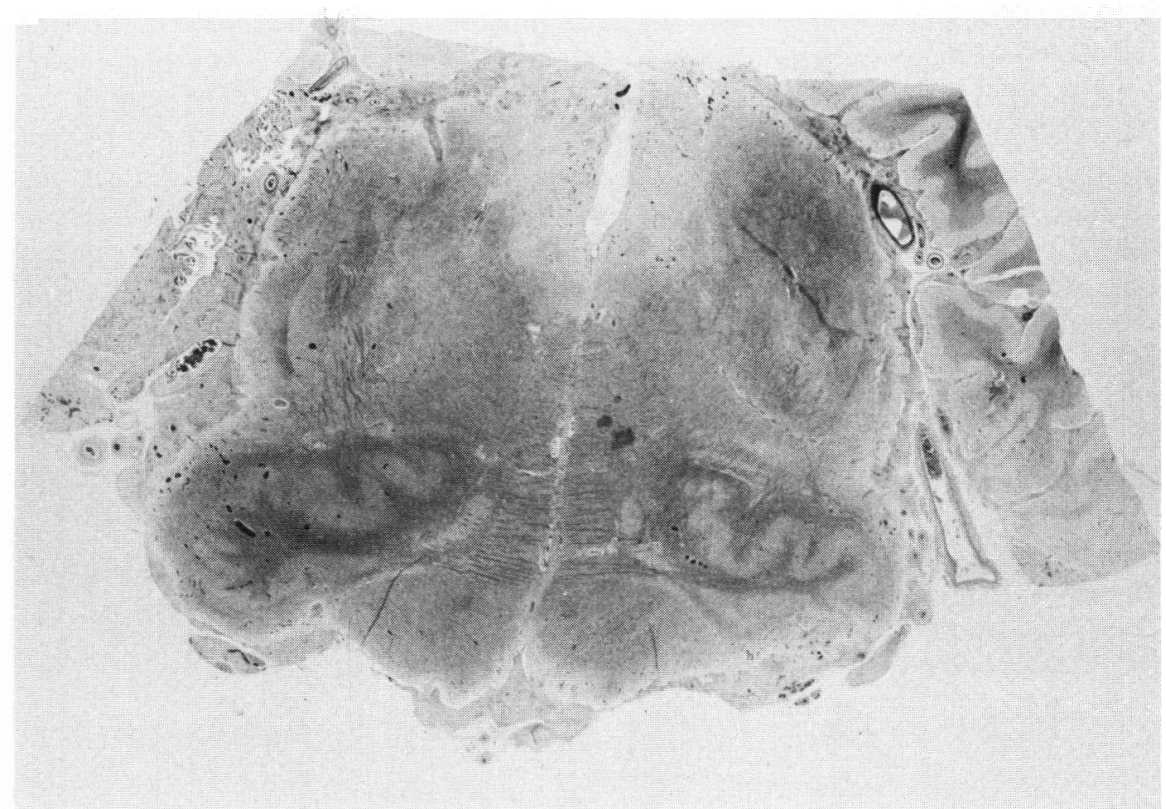

Figure 5 - The leptomeninges surrounding the medulla oblongata have been intensely infiltrated by numerous sarcoid granulomas and become fibrotic. Thus, the foramina of Luschka are partly obliterated and the facial and statoacoustic nerves virtually destroyed. Marked infiltration and vascular. congestion are also seen in the walls of the fourth ventricle (LFB; x3.8)

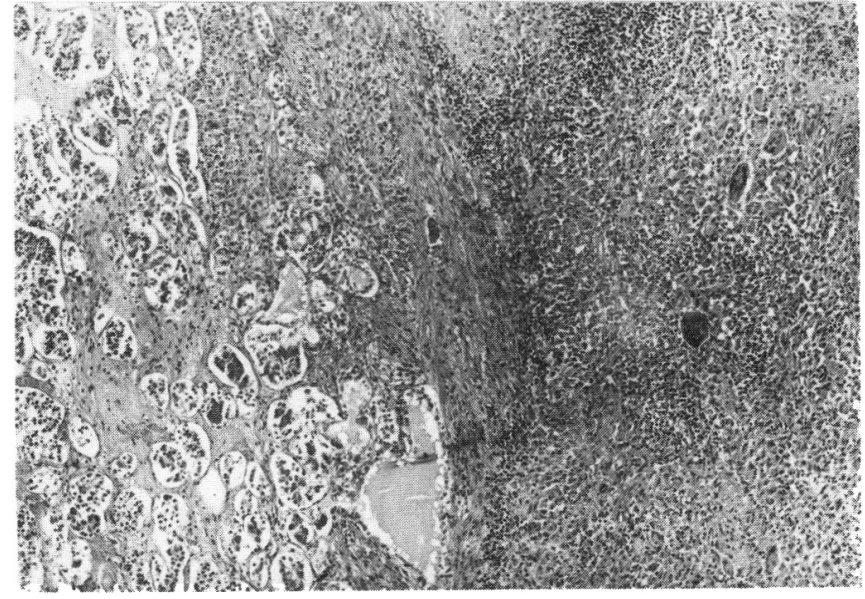

Figure 6 - In this field, the adenohypophysis (partly preserved in the left half of the field) is replaced by confluent epithelioid cell granulomas containing giant cells (HPS; $x 63$ )

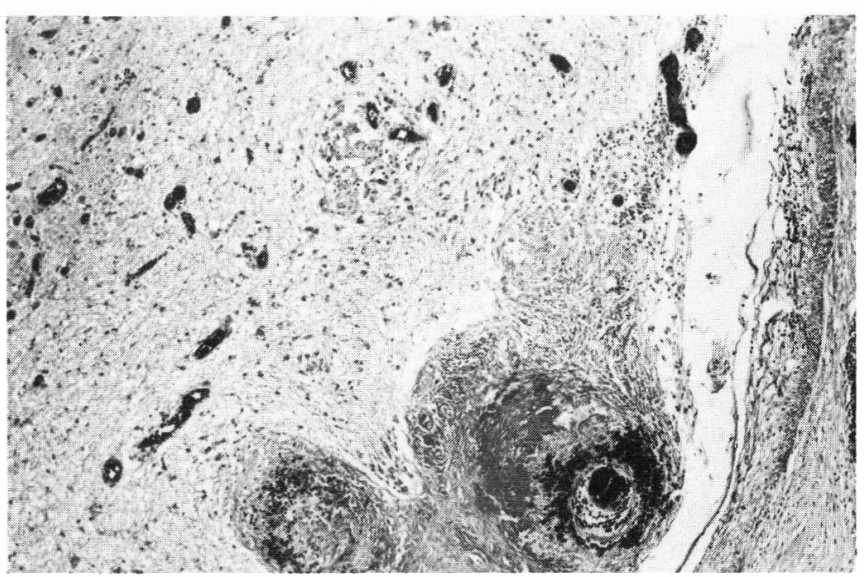

Figure 7 - Intense microvascular congestion of the medulla oblongata (inferior olivary nucleus in left upper corner) and intense fibrinoid necrosis and thrombosis of two small arteries are evident (Masson's trichrome; $x 63$ ). 


\section{DISCUSSION}

The prevalence of clinically manifest sarcoidosis of the nervous system in patients with the systemic disease has ranged from $1 \%$ (Douglas and Maloney, 1973), to $4.3 \%$ (Slade, 1979), to 16\% (Maycock et al, 1963). In postmortem series, neurosarcoidosis has been reported in approximately 15\% (Aszkanazy, 1952; Ricker and Clark, 1949; Waxman and Sher, 1979). Waxman and Sher (1979) have emphasized that granulomas consistent with sarcoidosis of the central nervous system are readily identified at necropsy in clinically asymptomatic cases, illustrating this phenomenon in two of their five cases. One must however, keep in mind the dictum that "... the diagnosis is established most securely when clinicoradiographic findings are supported by histological evidence of wide-spread noncaseating epithelioid cell granulomas in more than one organ..." (James et al, 1976). On the one hand, as is evident from the clinical literature cited above, neurosarcoidosis is a relatively uncommon manifestation of systemic dissemination of this granulomatous process. On the other hand, it may be the first or only clinical or pathological evidence of the disease. However, in the latter situation, there is the inherent problem of nosologic definition, since the differential diagnosis of granulomatous diseases is extremely broad (James and Neville, 1977).

If one downplays the "clinicoradiographic" findings and emphasizes the histologic criteria of non-caseating or hyalinized granulomas in several organs (James et al, 1976), my data seem to indicate that there may be clinically asymptomatic cases of sarcoidosis. The five cases in category I might constitute one end of the spectrum of sarcoidosis with no or only insignificant symptoms and spontaneous arrest with prolonged survival. These incidental cases had a mean age of 54.6 years at death from other causes. Those in category II with clinically apparent sarcoidosis, but no involvement of the CNS, died at an appreciably younger age (mean of 47.0 years) after an average duration of the disease of 6.7 years. Those patients, in category III, who had neurologic manifestations of sarcoidosis, died at a still younger age (mean, 38.2 years). After an interval averaging 3.2 years, their systemic sarcoidal process also affected the CNS, with a further mean course of 4.0 years of progressive and additive neurologic deficits. This third group then appears at the other end of the spectrum of sarcoidosis, with onset at a younger age, in volvement of the CNS early in the course of the disease, poor response to medical and/or neurosurgical modalities of therapy, and fairly rapid progression to death.

Where appropriate data were provided, similar trends can be calculated from published postmortem studies. In Ricker and Clark's (1949) series, the three patients with CNS involvement died at a mean age of 24 years contrasted with 17 patients without CNS involvement whose death occurred at an average of 31 years. In the seven cases of neurosarcoidosis of Herring and Urich (1969), the mean age at death was 37.4 years, with an average total duration of sarcoidosis of 8.3 years and of neurosarcoidosis of 4.7 years. Waxman and Sher (1979) reported five cases, having an average age of 33.2 years at death and a disease course of 2.3 years. Significantly, the two cases of incidental sarcoidosis of the cranial leptomeninges were the oldest patients, namely 43 and 50 years, in their series. This finding suggests that even neurosarcoidosis may span a spectrum, ranging from insignificant or no clinical manifestation to the most aggressive and fulminating form.

Many publications have emphasized the variety of syndromes caused by sarcoidosis of the CNS. The predilection of this granulomatous process for the leptomeninges at the cranial base accounts for the predominance of cases with neuroendocrine dysfunction due to involvement of hypothalamus, pituitary stalk, and hypophysis (Stuart et al, 1978); with cranial nerve palsies (Colover, 1948); with hydrocephalus (Kumpe et al, 1979); and with neuropsychiatric manifestations (Gilmore et al, 1980). A meningoencephalomyelitic process may cause various neurologic deficits and/or elevated intracranial pressure, spinal cord syndromes (Day \& Sypert, 1977), spinal nerve and nerve root disturbances, and large, tumor-like intracranial granulomatous masses (Delaney, 1977). As an additional pecularity, extending over months to years, the disease process is subject to remissions (either spontaneously or with treatment) and to relapses, but generally it runs a progressive course. Further, involvement of non-neural organs and systems by sarcoidal granulomas may cause metabolic, endocrinologic, and structural deficits which may secondarily affect the CNS. Vasculitis and cerebral infarcts have also been reported (Herring \& Urich, 1969). Finally, the systemic immune derangement in sarcoidosis facilitates infection of the CNS by opportunistic microbiologic agents (Mathews et al, 1976).

\section{ACKNOWLEDGEMENTS:}

The competent and diligent support of Mr. Dale Gibson, HT (ASCP) and Mrs. Elizabeth Ergueta is gratefully appreciated.

\section{REFERENCES}

Aszkanazy, C.L. (1952). Sarcoidosis of the central nervous system. J. Neuropath. Exp. Neurol. 11:392-400.

Colover, J. (1948). Sarcoidosis with involvement of the nervous system. Brain 71:451-475.

Day, A.L. and Sypert, G.W. (1977). Spinal cord sarcoidosis. Ann. Neurol. 1:79-85.

Delaney, P. (1977). Neurologic manifestations in sarcoidosis. Review of the literature, with a report of 23 cases. Ann. Intern. Med. 87:336-345.

Douglas, A.C. and Maloney, A.F.J. (1973). Sarcoidosis of the central nervous system. J. Neurol. Neurosurg. Psychiat. 36:1024-1033.

Gilmore, K., Rudden, M., and Kalman, T.P. (1980). Psychiatric manifestations of sarcoidosis. Can. J. Psychiatry 25:329-331.

Herring, A.B. and Urich, H. (1969). Sarcoidosis of the central nervous system. J. Neurol. Sci. 9:405-422.

James, D.G. and Neville, E. (1977). "Pathobiology of Sarcoidosis." In: Pathobiology Annual, Vol. 7, H.L. Ioachim, ed., pp. 31-61. Appleton-Century-Crofts, New York.

James, D.G., Turiaf, J., Hosoda, Y., Williams, W.J., Israel, H.L., Douglas, A.C., and Siltzbach, L.E. (1976). 
Description of sarcoidosis: report of the subcommittee on classification and definition. Ann. N.Y. Acad. Sci. 278:742.

Kumpe, D.A., Rao, C.V.G.K., Garcia, J.H., and Heck, A.F. (1979). Intracranial neurosarcoidosis. J. Comput. Assist. Tomogr. 3:324-330.

Mathews, T., Wisotzky, H., and Moossy, J. (1976). Multiple central nervous system infections in progressive multifocal leukoencephalopathy. Neurology 26:9-14.

Ricker, W. and Clark, M. (1949). Sarcoidosis. A clinicopathologic review of three hundred cases, including twenty-two autopsies. Am. J. Clin. Pathol. 19:725-749.
Slade, W.R. (1979). Sarcoid of the nervous system. J. Nat. Med. Assoc. 71:1205-1208.

Stuart, C.A., Neelon,. F.A., and Lebovitz, H.E. (1978). Hypothalamic insufficiency: The cause of hypopituitarism in sarcoidosis. Ann. Intern. Med. 88:589-594.

Urich, H. (1976): The optic pathway in neurosarcoidosis. Ann. N.Y. Acad. Sci. 278:406-415.

Waxman, J.S. and Sher, J.H. (1979). The spectrum of central nervous system sarcoidosis. A clinical and pathologic study. Mt. Sinai J. Med. 46:309-317. 